\title{
Contrasting perception of fish trophic level from stomach content and stable isotope analyses: A Mediterranean artificial reef experience
}

\author{
Pierre Cresson ${ }^{1, *}$, Sandrine Ruitton, Mélanie Ourgaud, Mireille Harmelin-Vivien
}

\author{
Aix Marseille Univ, CNRS INSU, IRD, MIO,UM 110, F-13288 Marseille, France. \\ ${ }^{1}$ Present address : IFREMER, Lab Environm \& Ressources Provence Alpes, Côte d'Azur, Zone portuaire de \\ Brégaillon, BP 330, 83507 La Seyne sur Mer Cedex \\ *: Corresponding author : Pierre Cresson, tel.: + 33494304874 ; fax: + 33494304417 ; \\ email address : pierre.cresson@ifremer.fr
}

\begin{abstract}
:
A large complex of artificial reefs was deployed in the Bay of Marseilles, North-Western Mediterranean, for the enhancement of commercial fisheries stocks. Carbon and nitrogen stable isotope and stomach content analyses were performed on 23 fish species collected on the artificial reefs to assess their trophic position and feeding behaviour. Results indicated that fish diets were not modified on the artificial reefs compared to natural environments, nor was the structure of their trophic network. Artificial reefs, with their complex design, provide diverse and abundant food sources for fishes. Ranges of $\delta^{13} \mathrm{C}$ and $\delta^{15} \mathrm{~N}$ of artificial reef fishes were comparable to those recorded in natural Mediterranean environments, with a similar trophic organization. However, some discrepancies appeared when comparing fish trophic level based on isotopic or diet results, which calls for a careful interpretation of stable isotope values as direct indicators of trophic level.
\end{abstract}

\section{Highlights}

Fish diets were assessed on artificial reefs. $>$ Stomach content and stable isotope data are similar to those of natural environments. Artificial reefs provide diverse food sources for fishes, particularly crustaceans. Discrepancy may occur between $\delta^{15} \mathrm{~N}$ and fish diet. Trophic level estimation should not be based on $\delta^{15} \mathrm{~N}$ value alone.

Keywords: Artificial reefs ; Fish diet ; NW Mediterranean ; Stable isotopes ; Stomach content ; Trophic level 


\section{Introduction}

In a context of multiple human impacts on marine ecosystems, artificial reefs have been widely deployed in marine coastal waters to restore degraded habitats, enhance commercial and recreational fisheries, promote biodiversity and to protect benthic habitats, among other management goals (Jensen, 2002; Seaman, 2007). As artificial reefs represent large-scale experiments, they also provide a way to study ecosystem functioning and to elucidate ecological processes (Miller, 2002). Ecological hypotheses can be tested by comparing biological variables (eg. colonization kinetics, recruitment, biomasses, species richness, etc.) observed on similar modules modified or untreated to serve as controls (Charbonnel et al., 2002). By the creation of new habitats and increasing food resources, the deployment of artificial reefs can be a useful tool for enhancing fish biomass and sustaining small-scale coastal fisheries (Charbonnel et al., 2002; Scarcella et al., 2011; Steimle and Ogren, 1982). In the Mediterranean Sea, fishing pressures are strong on populations, since $50 \%$ of the assessed stocks, like mullets or seabreams, are considered overexploited (FAO, 2012). Artificial reefs are nowadays considered by all stakeholders as an efficient tool to support small-scale fisheries and also to restore coastal zone under strong fishing pressure (Claudet and Pelletier, 2004). As fishing targets generally high trophic level species, overfishing is commonly acknowledged to modify the structure of fish community and decrease fish mean trophic levels (Pauly et al., 1998). A good understanding of human pressures on marine ecosystems requires thus robust indicators of fish trophic level.

Studies on trophic patterns of Mediterranean fish have classically and extensively been performed by stomach content analysis (Bell and Harmelin-Vivien, 1983; Morte et al., 2001; Rosecchi, 1987; Šantić et al., 2011; and references in Stergiou and Karpouzi, 2002). This technique allows for the identification of the prey actually consumed by a fish and gives a "snapshot" of its recent diet. However, some biases linked with accurate prey identification or different rates of prey digestion may be problematic when using this technique. Moreover, the low temporal resolution of this technique requires a large number of samples to obtain a representative view of the dietary patterns of a species (Hyslop, 1980). Some of these biases can be solved using stable isotope analysis. Isotopic ratios of carbon and nitrogen have been used to describe trophic relationships in marine Mediterranean ecosystems (Deudero et al., 2004; Jennings et al., 1997; Pinnegar and Polunin, 2000). When consuming a prey, a predator integrates the $\mathrm{C}$ and $\mathrm{N}$ isotopic ratios of its prey into its own tissues. A fractionation process occurs at each trophic level, as the $\delta^{13} \mathrm{C}$ of the predator is generally slightly higher than the $\delta^{13} \mathrm{C}$ of its prey $(\sim+1 \%$ per trophic level), allowing the use of the carbon isotopic ratio as an indicator of the organic matter origin. The fractionation factor is higher for nitrogen (theoretically $+3.4 \%$ per trophic level) and $\delta^{15} \mathrm{~N}$ was classically used as a direct indicator of the trophic level of the predator (Post, 2002). Nevertheless, due to biases linked with isotopic ratios of the trophic baseline (ie $\delta^{15} \mathrm{~N}$ value of the source of organic matter at the base of the trophic network) and variability of nitrogen fractionation factor, some recently published papers call for a cautious use of $\delta^{15} \mathrm{~N}$ as a direct indicator of trophic level (Mancinelli et al., 2013; Post, 2002).

Through the "RECIFS PRADO" program, 400 artificial reefs were installed in a 220 ha area between 25 and $35 \mathrm{~m}$ depth in the Bay of Marseilles in 2007 and 2008. "RECIFS PRADO" is the largest artificial reef program in the Mediterranean Sea and represents the deployment of a total volume of $\sim 27000 \mathrm{~m}^{3}$ of artificial concrete structures. Its aim is to enhance fish biomass in the surroundings of artificial reefs and consequently sustain local small-scale coastal fisheries. This program represented a valuable opportunity 1) to assess the trophic organization of an artificial reef fish community using stable isotope and stomach content analyses and 2) to compare the use of $\delta^{15} \mathrm{~N}$ values and diet composition in determining the trophic level of coastal fish. 


\section{Materials and Methods}

Fish were collected on two artificial reefs in the "RECIFS PRADO" zone in the Bay of Marseilles, France (Fig. 1). These large reefs $\left(6 \mathrm{~m}\right.$ high, $\left.187 \mathrm{~m}^{3}\right)$ are composed of steel and concrete modules. Their complexity was increased by the addition of bags filled with dead oyster shells (hereafter named oyster bags) creating shelters for small organisms (Charbonnel et al., 2011). Their size and complexity provide habitats of different sizes suitable for most coastal organisms and allow efficient and standardized sampling procedures. The two artificial reefs investigated, one in the north (V3 reef) and the other in the south (V6 reef) of the zone, were chosen according to differences in distance from some organic matter sources (Huveaune River and Posidonia oceanica meadows) and management status (Cresson et al., 2012). The whole artificial reef zone is currently a full notake area but the southern part will be opened to small-scale artisanal fisheries in a few years. V3 and V6 artificial reefs are located at $30 \mathrm{~m}$ depth on similar sandy bottom with dead matte of $P$. oceanica (underlying structure of $P$. oceanica meadows constituted of rhizomes and roots intermingled with sediments).

A total of 339 fishes belonging to 32 species were sampled on the artificial reefs by spear fishing and trammel nets in summer and winter 2010. Species for which only one or two individuals were collected were discarded and the resulting 325 fishes belonging to 23 species (Table 1) were used for isotopic and stomach content analyses. Details on the number of fish actually sampled at each season on each reef are presented in Table S1.

In the laboratory, each fish was measured (standard length to the nearest $\mathrm{cm}$ ) and weighed (total mass to the nearest $\mathrm{g}$ ) before dissection. White dorsal muscle was taken for isotopic analyses before freeze-drying and grinding. In temperate fishes, lipid concentration in white muscle is generally low and this tissue was demonstrated to be the most suitable for stable isotope analysis (Pinnegar and Polunin, 1999). Lipid content was assessed by the C/N ratio. A C/N value lower than 3.5 generaly indicates a lipid content too low to bias the isotopic ratios (Sweeting et al., 2006). In the whole dataset, less than 10 values were higher than this threshold and were removed to prevent this bias.

Stable isotope measurements were performed with a continuous-flow isotope-ratio mass spectrometer (Delta V Advantage, Thermo Scientific, Bremmen, Germany). Results are expressed in $\delta$ notation relative to PeeDee Belemnite and atmospheric $\mathrm{N}_{2}$ for $\delta^{13} \mathrm{C}$ and $\delta^{15} \mathrm{~N}$, respectively, according to the equation $\delta X=\left(\frac{R_{\text {sample }}}{R_{\text {standard }}}-1\right) \times 10^{3}$, where $\mathrm{X}$ is ${ }^{13} \mathrm{C}$ or ${ }^{15} \mathrm{~N}$ and $\mathrm{R}$ is the isotope ratio ${ }^{13} \mathrm{C} /{ }^{12} \mathrm{C}$ or ${ }^{15} \mathrm{~N} /{ }^{14} \mathrm{~N}$, respectively. For both $\delta^{13} \mathrm{C}$ and $\delta^{15} \mathrm{~N}$, measurement precision is $<0.1 \%$ o (replicate measurements of internal laboratory standards, acetanilide). The trophic level of fish species based on isotopic analysis was assessed using the formula adapted from Badalamenti et al. (2002): $\mathrm{TL}_{\mathrm{i}}=1+\left(\delta^{15} \mathrm{~N}_{\mathrm{i}}-\delta^{15} \mathrm{~N}_{\mathrm{TB}}\right) / 3.4$, where $\mathrm{i}$ is the fish species, $\delta^{15} \mathrm{~N}_{\mathrm{i}}$ is the nitrogen isotopic ratio for species $\mathrm{i}, 3.4$ the theoretical enrichment at each trophic level and $\delta^{15} \mathrm{~N}_{\text {TB }}$ the nitrogen isotopic ratio for pelagic or benthic primary production at the base of the trophic network. For pelagic production, the $\delta^{15} \mathrm{~N}$ of nanophytoplankton $\left(\delta^{15} \mathrm{~N}=1.77 \%\right.$, Rau et al., 1990) was used as previous results confirmed its dominance in the Bay of Marseilles (Gregori et al., 2001). Value used for benthic production $\left(\delta^{15} \mathrm{~N}=3.91 \%\right.$ ) is the mean annual value measured for macroalgae sampled on the artificial reefs (P. Cresson, unpubl. data).

Fish stomachs were removed and stored in $95 \%$ ethanol. Prey items in stomach contents were sorted under a binocular microscope into their lowest possible taxonomic groups and their wet weight was obtained to the nearest $0.01 \mathrm{mg}$. The relative importance of prey taxa in a fish species" diet was assessed by the weight percentage of a food type relative to the total 
weight of all food ingested. To assess the relative importance of the different prey types for the whole fish assemblage collected on the artificial reefs, relative importance by weight was calculated for each prey species. As pisicivores were heavier than other species and consumed heavy prey, the importance of prey type by weight was corrected by the mean fish weight. Thus, for each fish species, the consumed mass of each food item was divided by the mean weight of the species. The cumulative weight of each food item was then calculated for all fish species consuming this prey. Similarly, the overall occurrence of each prey type was considered as the percentage of species containing this prey (Hyslop, 1980). The trophic level of each fish species was issued from bibliographic data based on stomach content analyses (Barreiros et al., 2002; Darnaude, 2005; Rogdakis et al., 2010; Stergiou and Karpouzi, 2002; Soares et al., 2003).

Hierarchical clustering based on normalized Euclidean distance and Ward"s criterion was performed first on mean isotopic ratios to identify groups of species with similar isotopic ratios. The same procedure was applied independently to mean stomach content results to group together species having similar feeding strategies. The results of the two clusterings were compared. All statistical analyses were performed using R software and the "cluster" package (Maechler et al., 2012; R Core Team, 2012)

\section{Results}

\subsection{Stable isotope ratios of fishes}

Mean isotope values measured for fishes collected on the artificial reefs displayed a $2 \%$ range for $\delta^{13} \mathrm{C}\left(-19.73\right.$ to $-17.66 \%$ ) and a $7 \%$ (7.83 to $14.87 \%$ ) for $\delta^{15} \mathrm{~N}$ (Fig. 2), with few spatial or seasonal differences of fish isotopic ratios (Tab. S2). Six groups of species were individualized by hierarchical clustering based on their isotopic ratios (SI1 to SI6). SI1 group comprised three species (Boops boops, Spicara maena and Spicara smaris) and was characterized by the lowest values of both $\delta^{13} \mathrm{C}$ and $\delta^{15} \mathrm{~N}$ (Table 1). Three groups (SI2 to SI4) with intermediate $\delta^{13} \mathrm{C}$ and $\delta^{15} \mathrm{~N}$ values were distinguished. One (SI2) was composed of species belonging to the family Labridae (Coris julis, Symphodus mediterraneus and Symphodus tinca), and exhibited relatively low values for $\delta^{13} \mathrm{C}$ and $\delta^{15} \mathrm{~N}$. The three Diplodus species (Diplodus vulgaris, D. sargus and D. annularis) clustered together in the SI3 group, and exhibited relatively high $\delta^{15} \mathrm{~N}$ values. The SI4 group, comprising 11 species, was heterogeneous and displayed high $\delta^{13} \mathrm{C}$ (from - 18.36 to $-17.66 \%$ ) and intermediate $\delta^{15} \mathrm{~N}$ values (from 9.76 to $10.73 \%$ ). Sphyraena viridensis clustered apart in the SI5 group with low $\delta^{13} \mathrm{C}$ but rather high $\delta^{15} \mathrm{~N}(>11 \%)$. Finally, two species, Dicentrarchus labrax and Trachurus mediterraneus, formed the SI6 group, which was characterized by the highest $\delta^{15} \mathrm{~N}$ ratios $(>13 \%)$.

\subsection{Stomach content analysis}

The analysis of stomach contents revealed the overall importance of crustaceans and fishes as prey for the whole fish assemblage collected on the artificial reefs (Fig. 3). Crustaceans were the most frequent prey item consumed ( $80 \%$ of occurrence), followed by molluscs $(61 \%)$ and polychaetes (52\%). Crustaceans were also the most important prey by weight, followed by primary producers (macroalgae and $P$. oceanica) and fishes. Five feeding groups were identified by hierarchical clustering on stomach contents (Table 2, Fig. 4): "zooplankton feeders", "muddy/sand bottom mesocarnivores" (hereafter called soft bottom mesocarnivores), "rocky/seagrass bed bottom mesocarnivores" (hereafter called rocky bottom mesocarnivores), "macrocarnivores" and "piscivores". Feeding group designation took 
into account not only differences in prey consumed, but prey size (larger in macro- than in mesocarnivores) and habitat (water column, soft and hard bottom).

\subsection{Comparison of isotopic and dietary results}

Full concordance between isotopic and feeding groups occurred only for zooplankton feeders (Fig. 4). The three species of the SI1 group (B. boops, S. maena and S. smaris) fed mainly on zooplanktonic crustaceans (particularly copepods), even if slight differences could be observed between them. The diets of $S$. maena and $S$. smaris were almost exclusively composed of zooplanktonic crustaceans $(>75 \%)$, whereas $B$. boops displayed a more diverse diet, including fish eggs, gastropods, macroalgae and $P$. oceanica in addition to zooplanktonic crustaceans. Rocky bottom mesocarnivores belonged to two different isotopic groups, SI2 for labrids and SI3 for Diplodus spp. Labrid species consumed mainly bivalves and polychaetes, but in different proportions (Table 2). S. tinca consumed mostly polychaetes and to a lesser extent bivalves and gastropods, while bivalves dominated the diets of $C$. julis and S. mediterraneus (86\% and $45 \%$ respectively). The diets of the three Diplodus species (SI3) were more diverse and sessile organisms (macroalgae, ascidians, bryozoans, cnidarians and hydrozoans) were largely consumed. However, each species appeared to rely mainly on one food item, primary producers for $D$. annularis, polychaetes for $D$. sargus and, to a lesser extent, ascidians for $D$. vulgaris. Soft bottom mesocarnivores all belonged to the SI4 isotopic group. Stomach contents of $M$. variegatus, $M$. surmuletus, $P$. acarne, $P$. erythrinus and $T$. lastoviza were mainly composed of echinoderms and small benthic crustaceans, along with additional prey like polychaetes or cephalopods (Fig. 5). All macrocarnivores also belong to the SI4 group. The main prey observed in S. notata, $S$. porcus and $S$. cabrilla were large benthic crustaceans (brachyurans for $S$. notata and $S$. porcus, carids for $S$. cabrilla, Table 2). The highest discrepancy between isotopic and feeding clustering occurred for piscivores which were part of three different isotopic groups (SI4, SI5 and SI6). Synodus saurus, Scorpaena scrofa and Phycis phycis (SI4), Sphyraena viridensis (SI5), and Dicentrarchus labrax and Trachurus mediterraneus (SI6) displayed largely different isotopic signatures, while all preyed mainly on fishes (> $85 \%$, Table 2 , Fig. 5)

\subsection{Trophic level estimation}

The trophic level calculated from stable isotope values using a pelagic baseline matched the trophic level estimation based on stomach contents for most trophic groups: zooplankton feeders, labrids, soft bottom mesocarnivores, macrocarnivores and pelagic piscivores (Table 3). Calculations based on benthic isotopic baseline always indicated lower trophic levels for these groups. On the contrary, the trophic level of Diplodus spp from stomach contents better fitted the isotopic calculation based on benthic baseline, while the pelagic baseline led to a higher estimation. Eventually, the trophic level of benthic piscivores was always lower when calculated from isotopic values than from stomach contents, whatever the trophic baseline used.

\section{Discussion}

With the exception of gobiids, blennids and pomacentrids which could not be sampled due to their small size, the present study analysed the majority of the fish species observed by underwater visual censuses on the artificial reefs in the Bay of Marseilles (Rouanet et al., 2012). The most abundant species (sparids, scorpaenids, serranids, mullids) included in our 
study dominated also in natural rocky habitats (Fasola et al., 1997; Harmelin, 1987; Letourneur et al., 2003).

\subsection{Use of artificial reef food resources by fishes}

Fish diets on the artificial reefs were rather similar with those observed in natural environments in the area of Marseilles (Bautista-Vega et al., 2008; Bell and Harmelin-Vivien, 1983; Harmelin-Vivien et al., 1989) or in other Mediterranean zones (Fanelli et al., 2011; Kalogirou et al. 2012; Quignard, 1966; Sala and Ballesteros, 1997; Stergiou and Karpouzi, 2002), even if no direct comparison of diets in natural and artificial habitats could be performed in this work.

Stomach contents observed for Boops boops, Spicara smaris and S. maena placed them in the cluster of secondary consumers specialized on zooplanktonic organisms, as already observed (Bell and Harmelin-Vivien, 1983; Stergiou and Karpouzi, 2002). Different proportions of zooplankton and vegetal material were observed in the diet of the more opportunistic B. boops (Derbal and Kara, 2008; Fasola et al., 1997).

The majority of the fish species sampled on the artificial reefs exhibited a mesocarnivorous diet, based on small invertebrates (crustaceans, molluscs, echinoderms or polychaetes) and benthic primary producers. Taking into consideration the habitat of species allowed clearly distinguishing between rocky and sandy bottom fishes. Based on their diets, labrids and Diplodus species were gathered in the same feeding cluster of rocky bottom mesocarnivores. Labrids mainly consumed small benthic invertebrates like molluscs and polychaetes. $C$. julis is known to prey on gastropods and crustaceans (Quignard, 1966), juvenile echinoderms (Sala, 1997) or bivalves (Bell and Harmelin-Vivien, 1983). The diets of S. tinca and $S$. mediterraneus are similar and composed of small crustaceans, bivalves, gastropods and polychaetes (Bell and Harmelin-Vivien, 1983). Diplodus spp. can be considered as omnivores as they presented a diversified diet, feeding on a large range of prey, from primary producers to fishes, with a high consumption of diverse sessile invertebrates. Omnivory of Diplodus species is well documented (Derbal et al., 2007; Rosecchi, 1987; Sala and Ballesteros, 1997). The soft bottom mesocarnivores (M. variegatus, M. surmuletus, $P$. acarne, $P$. erythinus and $T$. lastoviza) preyed mainly on echinoderms and small crustaceans, along with other diverse prey like molluscs or polychaetes, consistently with previous results (Bautista-Vega et al., 2008; Fanelli et al., 2011; Fehri-Bedoui et al., 2009). The diet of macrocarnivores (S. notata, S. porcus and S. cabrilla) was also composed of crustaceans, but of larger size (brachyurans and carids), and in larger proportion (>90\% of the ingested prey weight) than mesocarnivores (Harmelin-Vivien et al., 1989). For all these species, the present study highlighted the importance of crustaceans in artificial reef functioning, which represented the most commonly ingested prey type. These results confirm the major role of crustaceans in fish diets on artificial reefs (Leitão et al., 2007; Relini et al., 2002). Finally, six species (Scorpaena scrofa, Phycis phycis, Trachurus mediterraneus, Sphyraena viridensis, Synodus saurus and Dicentrarchus labrax) mainly preyed on fish and could be considered as piscivores. Even if all these predators consume fishes, differences appeared nevertheless amongst them, as they occupied different habitats and consumed different species. Previous works report a high consumption of zooplankton feeding species ( $B$. boops and $S$. smaris) by $S$. viridensis, which could be consider as a pelagic piscivore (Kalogirou et al., 2012). P. phycis could be consider as a benthic piscivore, as remains of benthic species ( $C$. julis and $S$. tinca) were observed in its stomach contents on the artificial reefs. Previous works indicate also the consumption of B. boops, Spicara spp. or Chromis chromis by S. saurus and S. scrofa in natural environments (Esposito et al., 2009; Šantić et al., 2011). Finally, $T$. mediterraneus and $D$. labrax were high trophic level transient piscivores, as confirmed by the predominance of fish remains in their stomach, consistently to previous works (Pasquaud et al., 2010; Rogdakis et al., 2010). 


\subsection{Stable isotopes and the trophic structure of fish community}

Fishes sampled on the artificial reefs of Marseilles displayed a range of isotopic ratios ( $2 \%$ o for $\delta^{13} \mathrm{C}$ and $7 \%$ for $\delta^{15} \mathrm{~N}$ ) similar to those observed in previous studies of fish assemblages in natural Mediterranean coastal rocky environments (Jennings et al., 1997; Pinnegar and Polunin, 2000; Vizzini and Mazzola, 2009). Using $\delta^{15} \mathrm{~N}$ as an indicator of trophic level, it could be considered that fishes occupied at least three trophic levels on the artificial reefs studied. The lower level $\left(\delta^{15} \mathrm{~N}<9 \%\right)$ was occupied by the three zooplankton-feeders $(B$. boops, $S$. smaris and $S$. maena) which clustered in the SI1 group, the only one to be conserved between the two classifications. The specificity of their diets, both on specific and isotopic points of view, could explain the robustness of this group. The second intermediate trophic level $\left(9 \%<\delta^{15} \mathrm{~N}<13 \%\right.$ ) gathered most of the species sampled on the artificial reefs. However, four distinct isotopic groups of intermediate trophic level fishes were separated based on both their $\delta^{15} \mathrm{~N}$ and $\delta^{13} \mathrm{C}$ values, and these groups did not match with stomach content clustering. Within the rocky bottom mesocarnivorous group, difference in isotopic values placed labrids (SI2) and Diplodus spp. (SI3) in two distinct isotopic groups. The rather low isotopic values observed for labrids were consistent with the consumption of small low trophic level invertebrates, as previously observed in natural environments (Bell and Harmelin-Vivien, 1983; Quignard, 1966; Sala, 1997). Contrarily, the $\delta^{15} \mathrm{~N}$ observed for Diplodus spp. was surprisingly high for species consuming small invertebrates and primary producers, as it was higher than those of carnivorous species like $S$. porcus. A similar pattern between $\delta^{15} \mathrm{~N}$ ratios measured in Diplodus spp. and $S$. porcus is reported in other Mediterranean rocky environments. In Formentera, Balearic Islands, $D$. annularis displays a higher $\delta^{15} \mathrm{~N}$ ratio than S. porcus $(9.44 \%$ and $8.93 \%$ respectively, Deudero et al., 2004). In the Bay of Calvi, Corsica, Pinnegar and Polunin (2000) report also higher $\delta^{15} \mathrm{~N}$ values for $D$. annularis and D. sargus than for $S$. porcus (8.39, 9.13 and $7.93 \%$ respectively). These authors explain such high $\delta^{15} \mathrm{~N}$ values by the consumption of fishes by Diplodus spp., but have not analysed fish stomach contents. Such an explanation is likely not pertinent here due to the minor importance of fish in the diet of Diplodus spp. collected on the artificial reefs, and is confirmed by other studies on their feeding habits (Bell and Harmelin-Vivien, 1983; Derbal et al., 2007; Sala and Ballesteros, 1997). The apparent discrepancy between $\delta^{15} \mathrm{~N}$ values and diet for Diplodus spp. calls for cautious interpretation of isotopic ratios (see last paragraph). The SI4 group was the most diverse of intermediate trophic level fishes, as it gathered species classified with stomach contents as soft-bottom mesocarnivores, macrocarnivores and benthic piscivores. Finally, the pelagic Sphyraena viridensis clustered apart (SI5) at an intermediate trophic level in spite of a piscivorous diet. The highest trophic level $\left(\delta^{15} \mathrm{~N}>13 \%\right.$ ) was represented by two well-known piscivores, Dicentrarchus labrax and Trachurus mediterraneus (Rogdakis et al., 2010; Stergiou and Karpouzi, 2002).

Thus, in spite of apparently similar diets based on fish, piscivorous species displayed different isotopic ratios and were classified in three isotopic groups (SI4, SI5 and SI6). The comparable $\delta^{13} \mathrm{C}$ values of Sphyraena viridensis (SI5) and Boops boops, Spicara maena and $S$. smaris, along with the $\sim 3 \%$ higher $\delta^{15} \mathrm{~N}$ of $S$. viridensis, testified of the consumption of zooplanktivorous fishes by this piscivore, as observed by Kalogirou et al. (2012). The three benthic piscivorous species ( $S$. saurus, $S$. scrofa and $P$. phycis) displayed $\delta^{15} \mathrm{~N}$ values close to those of crustacean-eating mesocarnivores (SI4). This might appear surprising for fish consumers, generally considered to be at the highest trophic level in the Mediterranean (Stergiou and Karpouzi, 2002), but could be explained by the consumption of low trophic level benthic fish species. Finally, the high $\delta^{15} \mathrm{~N}$ value of $T$. mediterraneus and $D$. labrax (SI6) confirmed the high trophic level of these two piscivores (Pasquaud et al., 2010; Rogdakis et al., 2010). 


\section{3. $\delta^{15} \mathrm{~N}$ : a direct indicator of trophic level?}

Carbon and nitrogen stable isotope ratios have been widely used to assess trophic patterns in fish communities, sometimes replacing time-consuming stomach content analysis (Deudero et al., 2004; Jennings et al., 1997; Pinnegar and Polunin, 2000). In this approach $\delta^{15} \mathrm{~N}$ is considered as a direct indicator of the trophic position of consumers. However, recently published results demonstrated that different factors, like trophic baseline, isotopic fractionation and consumer metabolism among others, may bias direct trophic level interpretation (Mancinelli et al., 2013; Mill et al., 2007; Post 2002; Schmidt et al., 2004). Results of the current study illustrated some of these biases. Discrepancies were observed between the classifications based on stable isotope or stomach content analyses for all trophic groups except zooplankton feeders. The case of Diplodus spp. illustrated the influence of both trophic baseline isotopic ratios and trophic enrichment factor on the trophic level estimation of herbivorous (or omnivorous) versus carnivorous species (Mancinelli et al., 2013; Mill et al., 2007). A simplistic interpretation of the high Diplodus $\delta^{15} \mathrm{~N}$ could place these species at a high trophic level, just below the piscivorous $D$. labrax and $T$. mediterraneus, as suggested by the calculation of their trophic level from isotopic values. Such a position was incongruous with their omnivorous feeding patterns, as they consumed large amounts of algal matter and sessile invertebrates, along with other low trophic level prey. Diplodus $\delta^{15} \mathrm{~N}$ $(\sim 11 \%$ o) was surprisingly $\sim 2 \%$ higher than those of labrids, which belonged to the same trophic group of rocky bottom mesocarnivores (Fig. 4). Their $\delta^{15} \mathrm{~N}$ value could reflect the importance of algae or seagrass in their diet as benthic primary producers classically present higher $\delta^{15} \mathrm{~N}$ than phytoplankton (Nadon and Himmelman, 2006). The calculation of Diplodus spp. trophic level using a benthic baseline, rather than a pelagic one, resulted actually in a more consistent trophic level value, similar to the labrids one, and lower than those of piscivores. Recent works demonstrated also that fractionation factor associated with herbivory is higher than the usually-accepted $3.4 \%$ value, due to differences in the enzymatic and digestive systems of herbivorous species (Mill et al., 2007; Wyatt et al., 2010). The combined effects of prevalent benthic vegetal material in the diet of Diplodus spp., along with a higher fractionation factor, explained thus likely their high $\delta^{15} \mathrm{~N}$ values. This demonstrated how direct simplistic interpretation of isotopic ratios can lead to wrong inferences of consumers" diet and trophic level.

In the Mediterranean Sea, piscivorous species are considered to represent the highest trophic level for fishes, with a mean value close to or higher than 4 (Stergiou and Karpouzi, 2002). In the present study, the large range of $\delta^{15} \mathrm{~N}$ values $(10.1-14.9 \%$ ) recorded in the six piscivorous species analysed would place them at two distinct trophic levels. The lower trophic level of $S$. scrofa and $P$. phycis, when calculated from stable isotopes, was probably due to their consumption of crustaceans, in addition to fish. But some strictly piscivorous species, like $S$. viridensis and $S$. saurus, displayed an isotopic-calculated trophic level lower than 4 , as they consume zooplankton-eating or small benthic fishes, which presented themselves low $\delta^{15} \mathrm{~N}$ values. Inferring their diet and trophic level only from their $\delta^{15} \mathrm{~N}$ values that were similar to those of meso- and macrocarnivores (Fig.5), would have led to misinterpretations. On the contrary, the high $\delta^{15} \mathrm{~N}$ of $D$. labrax and T. mediterraneus were consistent with a trophic level higher than 4 , as previously calculated by Rogdakis et al. (2010). Using the specific $3.8 \%$ fractionation factor proposed for fish muscle $\delta^{15} \mathrm{~N}$ by Sweeting et al. (2007), D. labrax prey should exhibit $\delta^{15} \mathrm{~N}$ values close to $10 \%$, similar to those recorded for macrocarnivorous and other piscivorous fish species, which confirmed the consumption of high trophic level fishes by this predator. The current results confirmed the separation amongst fish-eating species proposed by Stergiou and Karpouzi (2002). A trophic level lower than 4 appear consistent for species eating fish and crustaceans. But a trophic level close to or higher than 4 for all fish-eating species can be questioned, since some species exhibit low $\delta^{15} \mathrm{~N}$ while preying only on fishes. Thus, "piscivore" is not always synonymous with "top-predator". 
The results obtained on the feeding habits and trophic position of artificial reef fishes in the Bay of Marseilles demonstrates that combining stable isotope and stomach content analyses remains a necessary approach to clarify fish trophic relationships, especially given that different prey types may present similar isotopic signatures (Layman et al., 2012). Even within one ecosystem, the crude comparison of $\delta^{15} \mathrm{~N}$ values of organisms does not necessarily reflect their trophic level and diet composition. The isotopic values measured in a consumer result not only from the isotopic ratios of its prey, but also from varying fractionation factors and food component routine (Perga and Grey, 2010; Schmidt et al., 2004; Sweeting et al., 2007). Thus, the correct interpretation of trophic relationships of organisms based on stable isotopic signatures is a highly complex task, which does not preclude the knowledge of their biology and feeding behaviour.

\section{Acknowledgements}

All fishes sampled with trammel nets were taken during experimental fishing by J.-Y. Jouvenel and members of "P2A Développement" team to whom we are grateful. Thanks are also expressed to B. de Ligondes F. Zuberer, G. Bleton (Scuba diving crew, OSU Pytheas) and to $\mathrm{F}$. Morat for their most valuable help during field sampling, especially in winter. Stable isotope analyses were performed by P. Richard and G. Guillou (LIENSs laboratory, Université de la Rochelle). We thank also the "GIS POSIDONIE" team for providing underwater censuses results and for valuable discussions and comments. English corrections of a previous version of the manuscript were done by Rachel Mackie.

This work is part of the „RECIFS PRADO"' program and was funded by grants from the city of Marseilles and the "Agence de l'Eau Rhône-Mediterranée-Corse".

\section{References}

Badalamenti, F., D"Anna, G., Polunin, N.V.C., 2002 Size-related trophodynamic changes in three target fish species recovering from intensive trawling. Mar. Biol. 141: 561-570.

Barreiros, J. P., Santos, R. S., de Borba, A. E., 2002. Food habits, schooling and predatory behaviour of the yellowmouth barracuda, Sphyraena viridensis (Perciformes: Sphyraenidae) in the Azores. Cybium 26, 83-88.

Bautista-Vega, A.A., Letourneur, Y., Harmelin-Vivien, M., Salen-Picard, C., 2008. Difference in diet and size-related trophic level in two sympatric fish species, the red mullets Mullus barbatus and Mullus surmuletus, in the Gulf of Lions (north-west Mediterranean Sea). J. Fish Biol. 73, 2402-2420.

Bell, J.D., Harmelin-Vivien, M.L., 1983. Fish fauna of French Mediterranean Posidonia oceanica seagrass meadow. 2. Feeding habits. Tethys 11, 1-14.

Charbonnel, E., Serre, E., Ruitton, S., Harmelin, J.-G., Jensen, A.C., 2002. Effects of increased habitat complexity on fish assemblages associated with large artificial reef units (French Mediterranean coast). ICES J. Mar. Sci. 59, S208-S213.

Charbonnel, E., Harmelin, J.G., Carnus, F., Le Direac'h, L., Ruitton, S., Lenfant, P., Beurois, J., 2011. Artificial reefs in Marseille (France, Mediterranean Sea): From complex natural habitat to concept of efficient artificial reef design. Braz. J. Oceanogr. 59, 177178.

Claudet, J., Pelletier, D., 2004. Marine Protected areas and artificial reefs: A review of the interactions between management and scientific studies. Aq. Liv. Ress. 17, 129-138. 
Cresson, P., Ruitton, S., Fontaine, M.-F., Harmelin-Vivien, M., 2012. Spatio-temporal variation of suspended and sedimentary organic matter quality in the Bay of Marseilles (NW Mediterranean) assessed by biochemical and isotopic analyses. Mar. Pollut. Bull. 64, 1112-1121.

Darnaude, A. M., 2005. Fish ecology and terrestrial carbon use in coastal areas: implications for marine fish production. J. Anim. Ecol. 74, 864-876.

Derbal, F., Kara, M.H., 2008. Composition du régime alimentaire du bogue Boops boops (Sparidae) dans le golfe d'Annaba (Algérie). Cybium 32, 325-333.

Derbal, F., Nouacer, S., Kara, M.H., 2007. Composition et variation du régime alimentaire du sparaillon Diplodus annularis (Sparidae) du golfe d'Annaba (Algérie). Cybium 32, 325-333.

Deudero, S., Pinnegar, J.K., Polunin, N.V.C., Morey, G., Morales-Nin, B., 2004. Spatial variation and ontogenic shifts in the isotopic composition of Mediterranean littoral fishes. Mar. Biol. 145, 971-981.

Esposito, V., Battaglia, P., Castriota, L., Finoia, M.G., Scotti, G., Andaloro, F., 2009. Diet of atlantic lizardfish Synodus saurus (Linnaeus, 1759) (Pisces: Synodontidae) in the Central Mediterranea Sea. Sci. Mar. 78, 369-376.

Fanelli, E., Baldamenti, F., D'Anna, G., Pipitone, C., Riginella, E., Azzuro, E., 2011. Food partitioning and diet temporal variation in two coexisting sparids Pagellus erythinus and Pagellus acarne. J. Fish Biol. 78, 869-900.

FAO, 2012. The state of world fisheries and aquaculture 2012, Rome, 209 pp.

Fasola, M., Canova, L., Foschi, F., Novelli, O., Bressan, M., 1997. Resource Use by a Mediterranean Rocky Slope Fish Assemblage. P. Z. N. I: Marine Ecology 18, 51-66.

Fehri-Bedoui, R., Mokrani, E., Ben Hassine, O.K., 2009. Feeding habits of Pagellus acarne (Sparidae) in the Gulf of Tunis, central Mediterranean. Sci. Mar. 73, 667-678.

Gregori, G., Colosimo, A., Denis, M., 2001. Phytoplankton group dynamics in the Bay of Marseilles during a 2-year survey based on analytical flow cytometry. Cytometry. 44, 247-256.

Harmelin, J.-G., 1987. Structure et variabilité de l'ichtyofaune d'une zone rocheuse protégée en Méditerranée (Parc national de Port-Cros, France). P. Z. N. I: Mar. Ecol. 8, 263284.

Harmelin-Vivien, M.L., Kaim-Malka, R.A., Ledoyer, M., Jacob-Abraham, S.S., 1989. Food partitionning among scorpaenid fishes in Mediterranean seagrass bed. J. Fish Biol. 34, 715-734.

Hyslop, E.J., 1980. Stomach contents analysis-a review of methods and their application. J. Fish Biol. 17, 411-129.

Jennings, S., Reñones, O., Morales-Nin, B., Polunin, N.V.C., Moranta, J., Coll, J., 1997. Spatial variation of the ${ }^{15} \mathrm{~N}$ and ${ }^{13} \mathrm{C}$ isotopes composition of plant, invertebrates and fishes, on Mediterranean reefs: implications for the study of trophic pathways. Mar. Ecol. Progr. Ser. 146, 109-116.

Jensen, A.C., 2002. Artificial reefs of Europe: perspective and future. ICES J. Mar. Sci. 59, S3-S13.

Kalogirou, S., Mittermayer, F., Pihl, L., Wennhage, H., 2012. Feeding ecology of indigenous and non-indigenous fish species within the family Sphyraenidae. J. Fish Biol. 80, 2528-2548.

Layman, C.A., Araujo, M.S., Boucek, R., Hammerschlag-Peyer, C.M., Harrison, E., Jud, Z.R., Matich, P., Rosenblatt, A.E., Vaudo, J.J., Yeager, L.A., et al., 2012. Applying stable isotopes to examine food-web structure: an overview of analytical tools. Biol. Rev. 87, 545-562.

Leitão, F., Santos, M.N., Monteiro, C.C., 2007. Contribution of artificial reefs to the diet of the white sea bream (Diplodus sargus). ICES J. Mar. Sci. 64, 473-478.

Letourneur, Y., Ruitton, S., Sartoretto, S., 2003. Environmental and benthic habitat factors structuring the spatial distribution of a summer infralittoral fish assemblage in the North-Western Mediterranean Sea. J. Mar. Biol. Ass. UK 83, 193-204. 
Maechler, M., Rousseeuw, P., Struyf, A., Hubert, M., Hornik, K.,2012. cluster: Cluster Analysis Basics and Extensions. R package version 1.14.2.

Mancinelli, G., Vizzini, S., Mazzola, A., Maci, S., Basset, A. 2013. Cross-validation of $\delta^{15} \mathrm{~N}$ and FishBase estimates of fish trophic position in a Mediterranean lagoon: the importance of isotopic baseline. Est. Coast. Shelf Sci. doi: 10.1016/j.ecss.2013.04.004.

Mill, A.C., Pinnegar, J.K., Polunin, N.V.C., 2007. Explaining isotope trophic-step fractionation: why herbivorous fish are different. Funct. Ecol. 21, 1137-1145.

Miller, M.W., 2002. Using ecological processes to advance artificial reef goals. ICES J. Mar. Sci. 59, 27-31.

Morte, S., Redon, M.J., Sanz-Brau, A., 2001. Diet of Scorpaena porcus and Scorpaena notata (Pisces : Scorpaenidae) in the Western Mediterranean. Cah. Biol. Mar. 42, 333-344.

Nadon, M.-O., Himmelman, J.H., 2006. Stable isotopes in subtidal food webs: Have enriched carbon ratios in benthic consumers been misinterpreted? Limnol. Oceanogr. 51, 2828-2836.

Pauly, D., Christensen, V., Dalsgaard, J., Froese, R., Torres, F., 1998. Fishing Down Marine Food Webs. Science 279, 860-863.

Pasquaud, S., Pillet, M., David, V., Sautour, B., Elie, P., 2010. Determination of fish trophic level in an estuarine system. Estuar. Coast. Shelf Sci. 86, 237-246.

Perga, M.E., Grey, J., 2010. Laboratory measures of isotope discrimination factors: comments on Caut, Angulo \& Courchamp (2008, 2009). J. Appl. Ecol. 47, 942-947.

Pinnegar, J.K., Polunin, N.V.C., 1999. Differential fractionation of $\delta^{13} \mathrm{C}$ and $\delta^{15} \mathrm{~N}$ among fish tissues : implication for the study of trophic interactions. Funct. Ecol. 13, 225-231.

Pinnegar, J.K., Polunin, N.V.C., 2000. Contributions of stable-isotope data to elucidating food webs of Mediterranean rocky littoral fishes. Oecologia 122, 399-409.

Post, D.M., 2002. Using stable isotopes to estimate trophic position: models, methods, and assumptions. Ecology 83, 703-718.

Quignard, J.P., 1966. Recherches sur les labridae (poissons téléostéens perciformes) des côtes européennes. Systématique et biologie. Causse et Castelnau, Montpellier, 1$248 \mathrm{pp}$.

R Core Team (2012). R: A language and environment for statistical computing. R Foundation for Statistical Computing, Vienna, Austria.

Rau, G.H., Teyssie, J.L., Rassoulzadegan, F., Fowler, S.W., $1990 .{ }^{13} \mathrm{C} /{ }^{12} \mathrm{C}$ and ${ }^{15} \mathrm{~N} /{ }^{14} \mathrm{~N}$ variations among size-fractionated marine particles: implications for their origin and trophic relationships Mar. Ecol.-Prog. Ser. 59, 33-38.

Relini, G., Relini, M., Torchia, G., De Angelis, G., 2002. Trophic relationship between fishes and an artificial reef. ICES J. Mar. Sci. 59, S36-S42.

Rogdakis, Y., Ramfos, A., Koukou, K., Dimitriou, E., Katselis, G., 2010. Feeding habits and trophic level of sea bass (Dicentrarchus labrax) in the Messolonghi-Etoliko lagoons complex (Western Greece). J. Biol. Res-Thessalon. 13, 13-26.

Rosecchi, E., 1987. L'alimentation de Diplodus annularis, Diplodus sargus, Diplodus vulgaris et Sparus aurata (Pisces : Sparidae) dans le golfe du Lion et les lagunes littorales. Rev. Trav. Inst. Pêches Marit. 49, 125-141.

Rouanet, E., Astruch, P., Le Direac'h, L., Bonhomme, D., Bonhomme, P., 2012. Opération Récifs Prado: Suivi scientifique, biologique et technique dans la zone d'immersion (suvi obligatoire). Rapport annuel 2012. Résultats. GIS Posidonie - Ville de Marseille, Fr, pp. 1-264.

Sala, E., 1997. Fish predator and scavengers of the sea urchin Paracentrotus lividus in protected areas of the North-Western Mediterranean Sea. Mar. Biol. 129, 531-539.

Sala, E., Ballesteros, E., 1997. Partitionning of space and food ressources by three fishes of the genus Diplodus (Sparidae) in a Mediterranean rocky infralittoral ecosystem. Mar. Ecol. Progr. Ser. 152, 273-283. 
Šantić, M., Pallaoro, A., Stagličić, N., Markov-Podvinski, M., 2011. Feeding habits of the red scorpionfish, Scorpaena scrofa (Osteichthyes: Scorpaenidae) from the eastern central Adriatic Sea. Cah. Biol. Mar. 52, 217-226.

Scarcella, G., Grati, F., Polidori, P., Domenichetti, F., Bolognini, L., Fabi, G., 2011. Comparison of growth rates estimated by otolith reading of Scorpaena porcus and Scorpaena notata caught on artificial and natural reefs of the northern Adriatic Sea. Braz. J. Oceanogr. 59, 32-42.

Seaman, W., 2007. Artificial habitats and the restoration of degraded marine ecosystems and fisheries. Hydrobiologia 580, 143-155.

Schmidt, K., McClelland J.W., Mente, E., Montoya, J.P., Atkinson, A., Voss, M., 2004. Trophic-level interpretation based on $\delta^{15} \mathrm{~N}$ values: implication of tissue-specific fractionation and amino-acid composition. Mar. Ecol. Prog. Ser. 266, 43-58.

Soares, M.S.C., Sousa, L., Barreiros, J. P., 2003. Feeding habits of the lizardfish Synodus saurus (Linnaeus, 1758) (Actinopterygii: Synodontidae) from the Azores. Aqua, J. Ichthyol. Aquat. Biol. 7, 29-38.

Steimle, F.L., Ogren, L., 1982. Food of fish collected on artificial reefs in the New York bight and Off Charleston, South Carolina. Mar. Fish. Rev. 44, 49-52.

Stergiou, K.I., Karpouzi, V.S., 2002. Feedings habits and trophic levels of Mediterranean fishes. Rev. Fish. Biol. Fisher. 11, 217-254.

Sweeting, C.J., Barry, J., Barnes, C., Polunin, N.V.C., Jennings, S., 2007. Effects of body size and environment on diet-tissue $\delta^{15} \mathrm{~N}$ fractionation in fishes. J. Exp. Mar. Biol. Ecol. 340, 1-10.

Sweeting, C.J., Polunin, N.V.C., Jennings, S., 2006. Effects of chemical lipid extraction and arithmetic lipid correction on stable isotope ratios of fish tissues. Rapid Commun. Mass Sp. 20, 595-601.

Vizzini, S., Mazzola, A., 2009. Stable isotopes and trophic position of littoral fishes from a Mediterranean marine protected area. Environ. Biol. Fishes 84, 13-25.

Wyatt, A.S.J., Waite, A.M., Humphries, S., 2010. Variability in isotope discrimination factors in coral reef fishes: implications for diet and food web reconstruction. PLoS ONE 5(10), e13682. doi:10.1371/journal.pone.0013682. 
Fig. 1: Location of artificial reefs (V3 and V6) in the Bay of Marseilles.

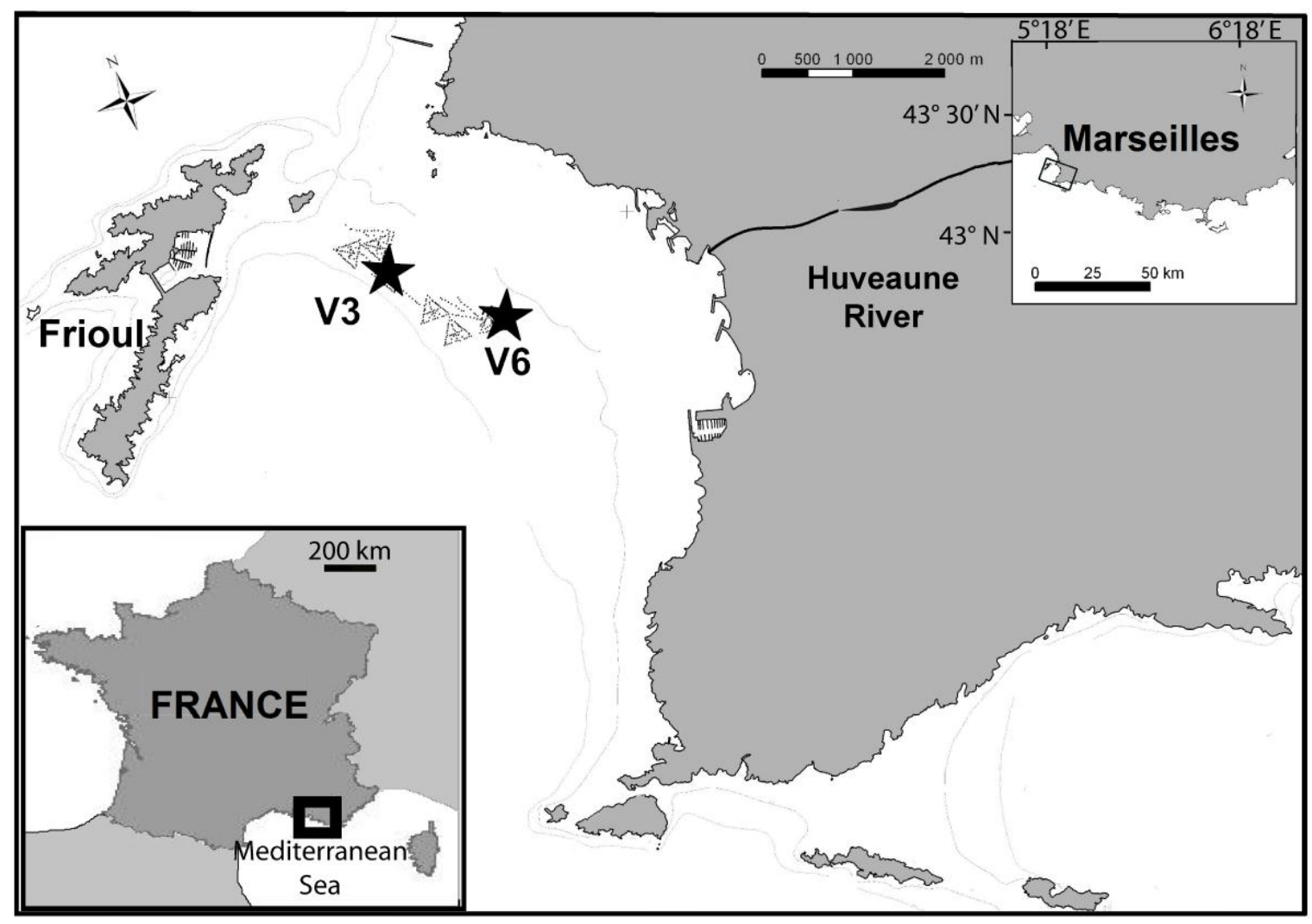


Fig. 2: Mean isotopic ratios $\left(\delta^{13} \mathrm{C}\right.$ and $\left.\delta^{15} \mathrm{~N}\right)$ of fishes sampled on artificial reefs. Species grouped together by the hierarchical clustering analysis are represented with similar symbols (white square: SI1; circle: SI2; triangles: SI3, diamonds: SI4, black square: SI5; crosses: SI6). Colours of the diamonds in the SI3 group represent the diet of the species (black: piscivores; grey: macrocarnivores; white: muddy/ sand bottom mesocarnivores). For graphical convenience, standard deviations are not plotted and the names of some species are abbreviated (S. medit: Symphodus mediterraneus, S. not: Scorpaena notata, M. sur: Mullus surmuletus, P. ery: Pagellus erythrinus).

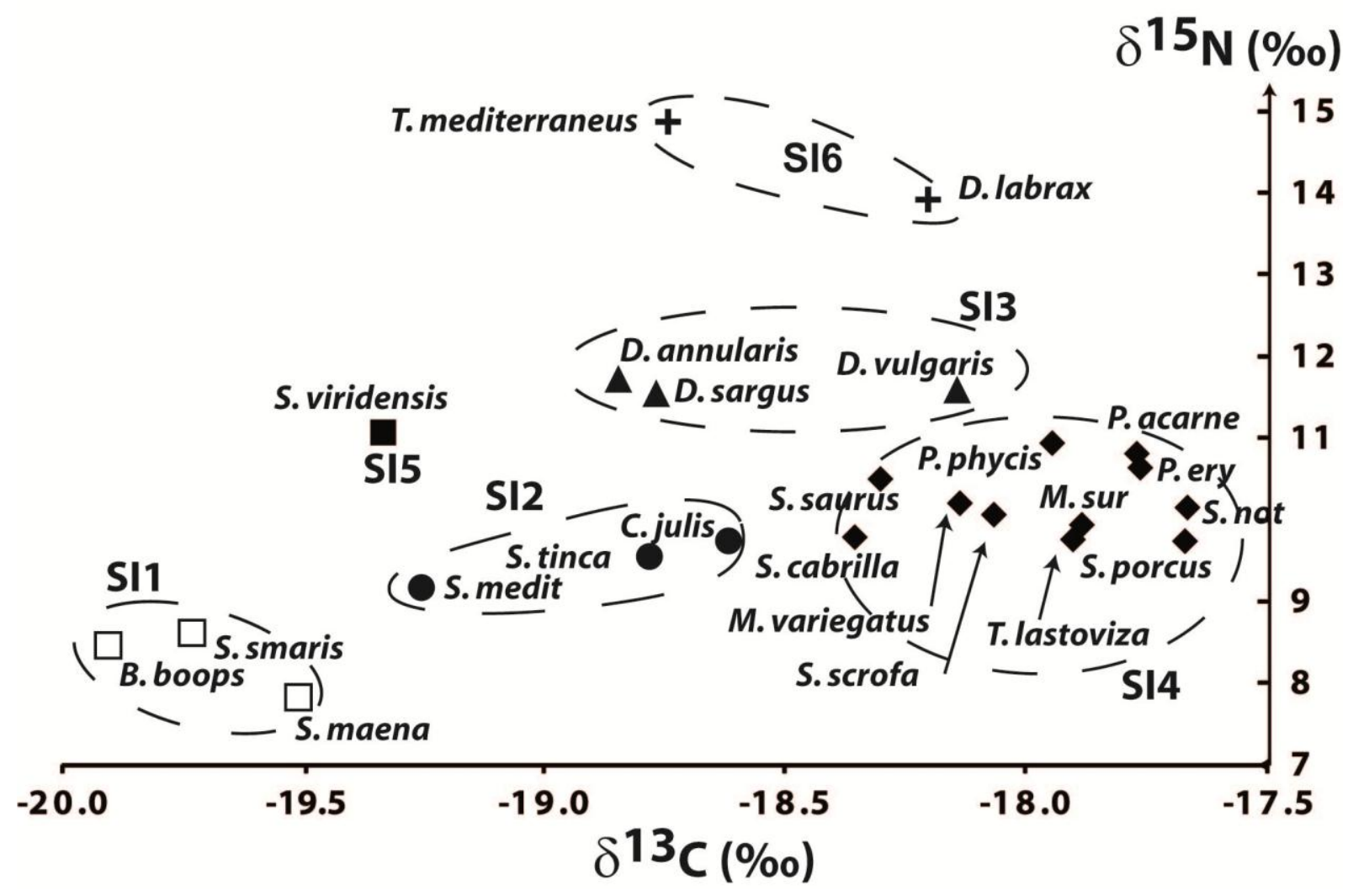


Fig. 3: Percentage of occurrence (black bars) and cumulative corrected mass (grey bars) of the main taxonomic groups of prey consumed by all the fish species analysed. Cnid. : Cnidarians

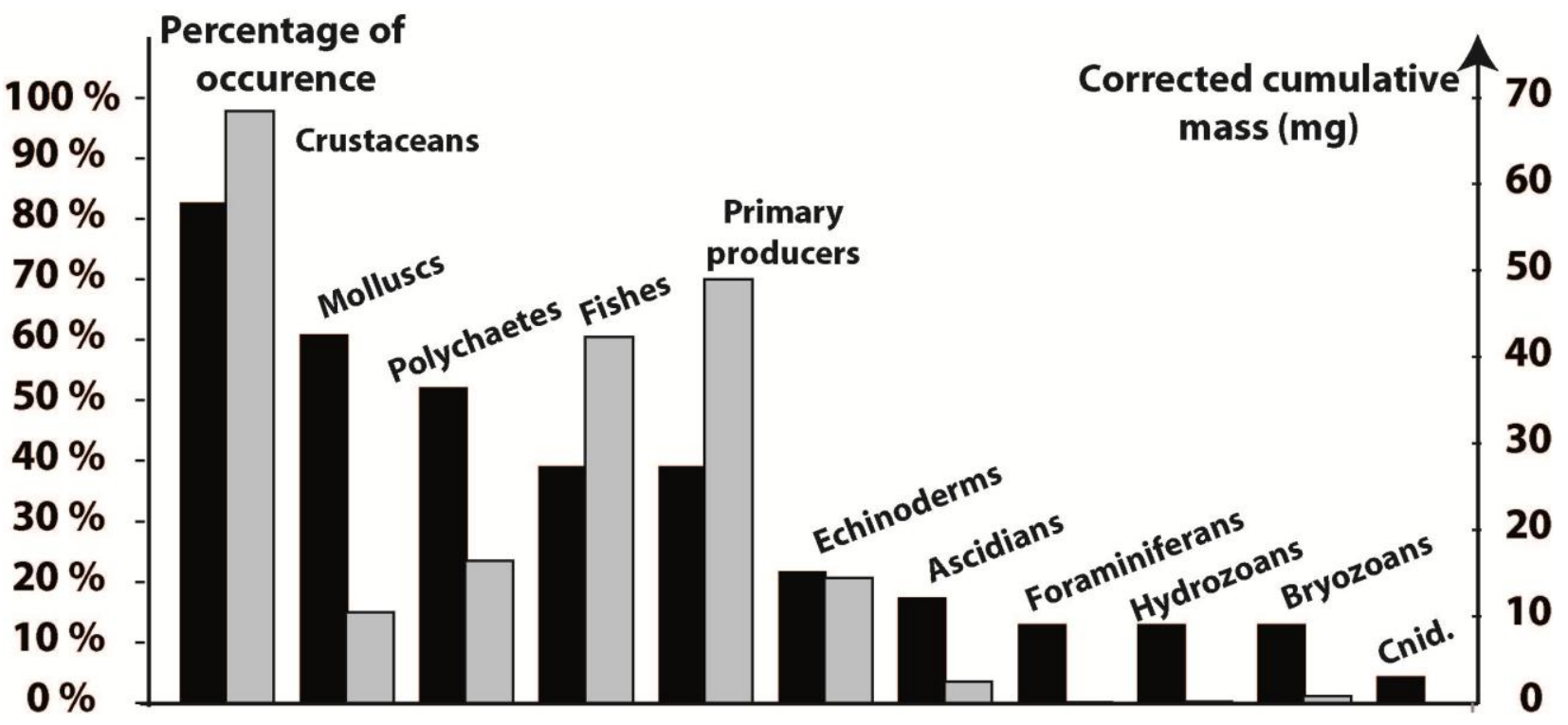

Fig.4: Hierarchical clustering tree based on stomach content analysis. The superimposed SI1 to SI6 indications represent the isotopic groups formed by an independent hierarchical clustering based on stable isotope ratios. They were added to evidence differences in clustering run with the two data sets.

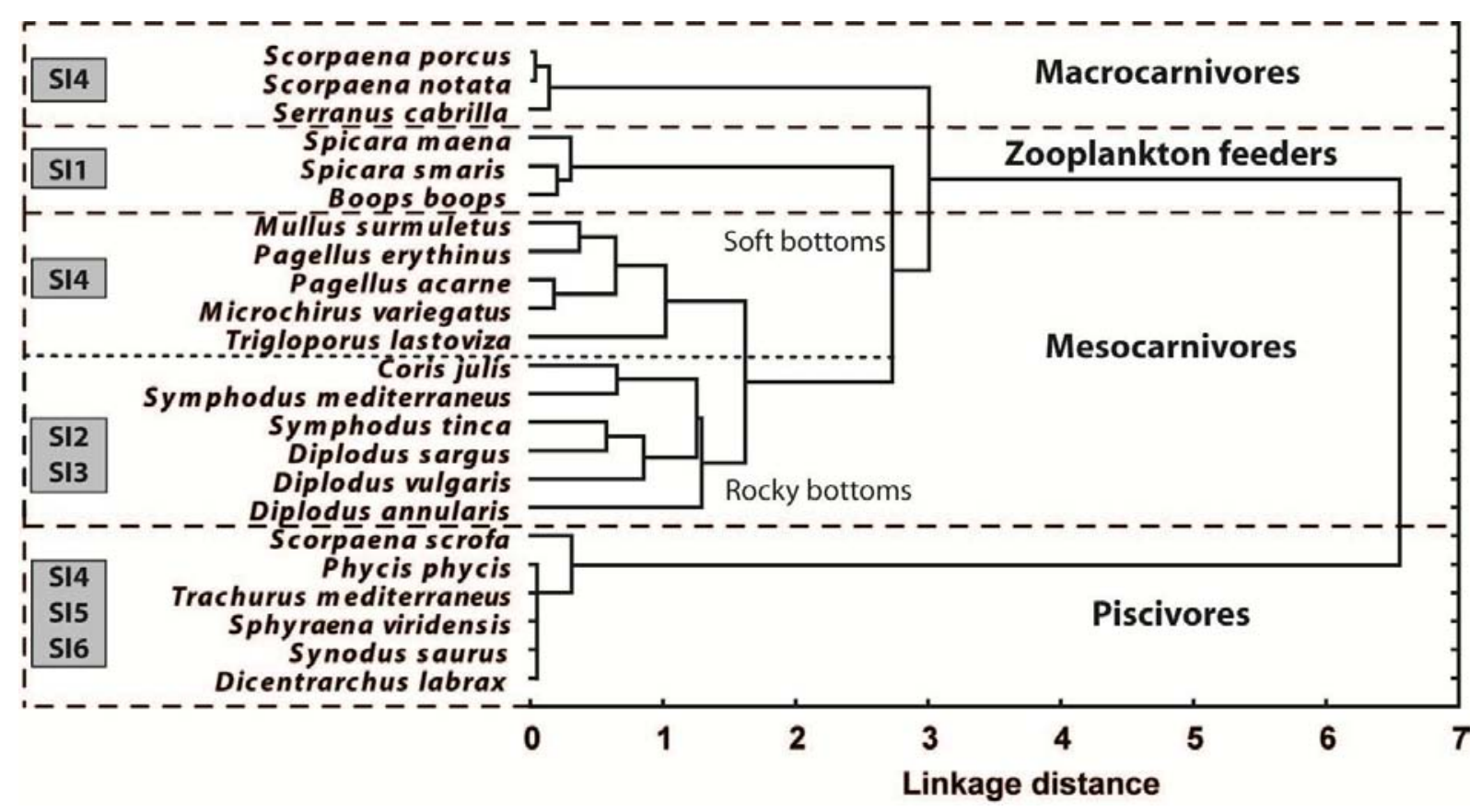


Fig. 5: Food spectra of nine species belonging to the SI4 group according to similar SI ratios but to three trophic groups according to different diets. Numbers after species names represent the number of stomachs analysed.

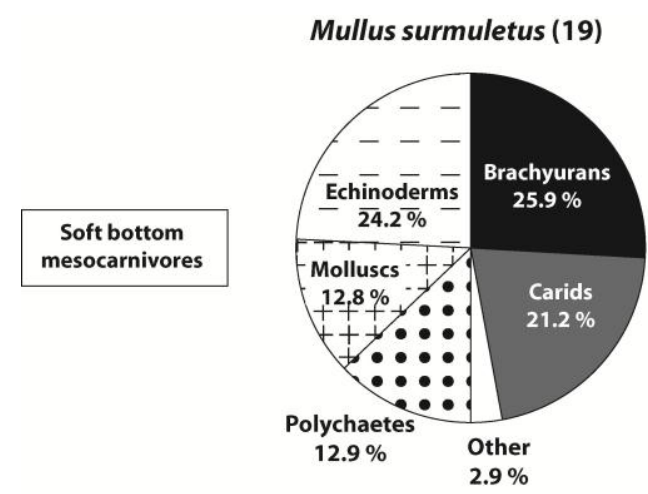

Scorpaena porcus (6)

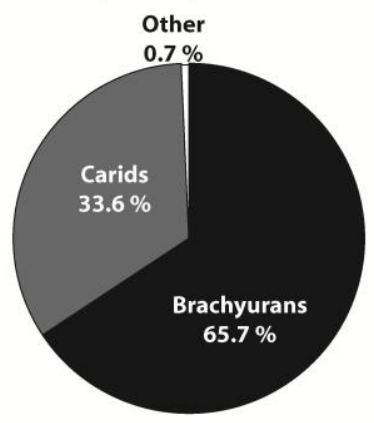

Phycis phycis (3)

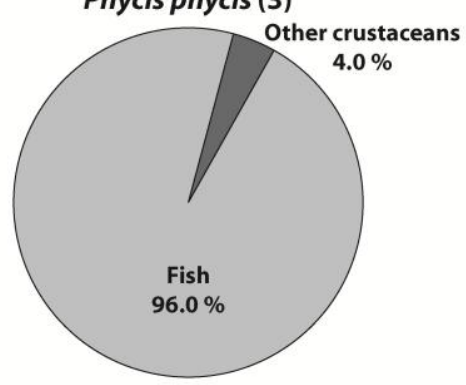

Pagellus erythrinus (3)

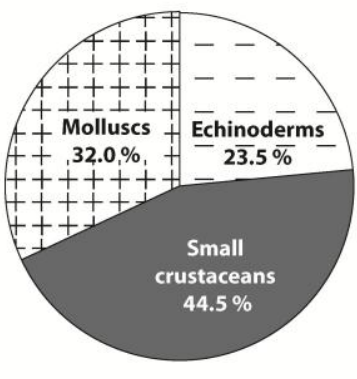

Scorpaena notata (27)

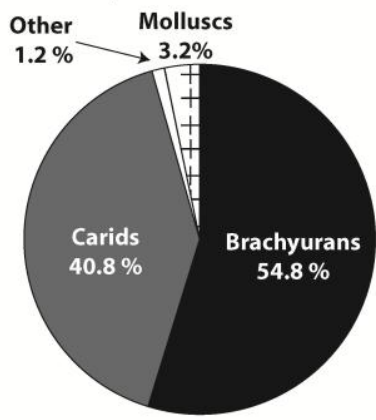

Scorpaena scrofa (3)

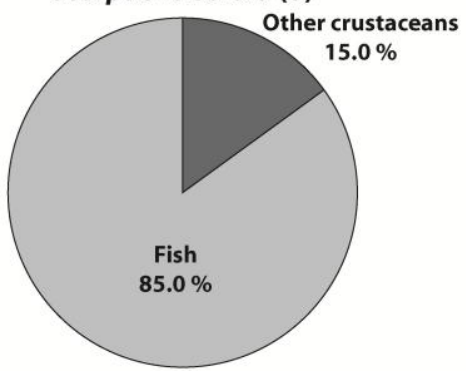

Pagellus acarne (11)

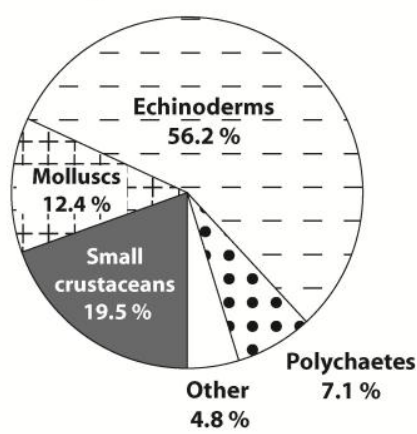

Serranus cabrilla (14)

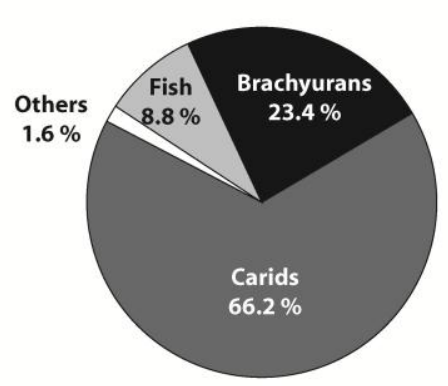

Synodus saurus (2)

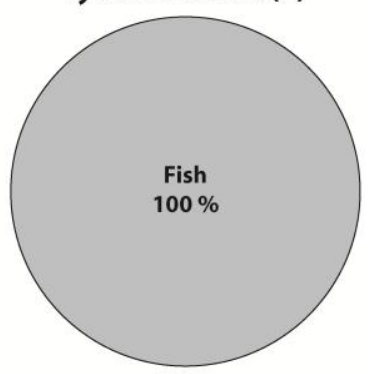


Table 1: Family, species, mean standard length (SL) and range (minimal and maximal length), mean mass and range (minimal and maximal mass), stable isotope ratios $\left(\delta^{13} \mathrm{C} \pm \mathrm{sd}, \delta^{15} \mathrm{~N} \pm \mathrm{sd}\right.$ ); numbers of fishes ( $\mathrm{n}$ indiv), of stable isotope analyses ( $\mathrm{n}$ SIA) and of stomach content analyses (SCA) realized.

\begin{tabular}{|c|c|c|c|c|c|c|c|c|c|c|}
\hline Family & Species & $\mathrm{SL}(\mathrm{mm})$ & Mass (g) & $\delta^{13} \mathrm{C}(\% 0)$ & sd & $\begin{array}{l}\delta^{15} \mathrm{~N} \\
(\% \circ)\end{array}$ & sd & $\mathrm{n}$ indiv & n SIA & n SCA \\
\hline \multirow[t]{2}{*}{ Carangidae } & Trachurus & & & & & & & & & \\
\hline & $\begin{array}{c}\text { mediterraneus } \\
\text { (Steindachner, } \\
1868)\end{array}$ & $259(236-277)$ & $231(215-245)$ & -18.74 & 0.77 & 14.87 & 2.98 & 5 & 10 & 4 \\
\hline \multirow[t]{2}{*}{ Centracanthidae } & $\begin{array}{c}\text { Spicara maena } \\
\text { (Linnaeus, 1758) }\end{array}$ & $131(104-170)$ & $62(35-101)$ & -19.51 & 0.33 & 7.83 & 0.25 & 10 & 26 & 6 \\
\hline & $\begin{array}{l}\text { Spicara smaris } \\
\text { (Linnaeus, 1758) }\end{array}$ & $141(116-154)$ & $63(45-104)$ & -19.73 & 0.41 & 8.61 & 0.77 & 9 & 13 & 5 \\
\hline \multirow[t]{4}{*}{ Labridae } & $\begin{array}{c}\text { Coris julis } \\
\text { (Linnaeus, 1758) }\end{array}$ & $109(68-144)$ & $19(5-45)$ & -18.62 & 0.55 & 9.74 & 0.31 & 13 & 18 & 13 \\
\hline & Symphodus & & & & & & & & & \\
\hline & $\begin{array}{c}\text { mediterraneus } \\
\text { (Linnaeus, 1758) }\end{array}$ & 109 (95-131) & $41(25-75)$ & -19.25 & 0.26 & 9.17 & 0.52 & 5 & 18 & 16 \\
\hline & $\begin{array}{l}\text { Symphodus tinca } \\
\text { (Linnaeus, 1758) }\end{array}$ & $158(115-213)$ & $110(35-250)$ & -18.78 & 0.84 & 9.55 & 0.52 & 6 & 15 & 12 \\
\hline Moronidae & $\begin{array}{c}\text { Dicentrarchus } \\
\text { labrax } \\
\text { (Linnaeus, 1758) }\end{array}$ & $325(267-430)$ & $\begin{array}{c}811 \\
(370-1870)\end{array}$ & -18.20 & 2.53 & 13.92 & 0.6 & 4 & 12 & 3 \\
\hline Mullidae & $\begin{array}{l}\text { Mullus surmuletus } \\
\text { Linnaeus, } 1758\end{array}$ & $142(91-216)$ & $75(20-225)$ & -17.88 & 0.72 & 9.94 & 0.67 & 35 & 44 & 19 \\
\hline Phycidae & $\begin{array}{c}\text { Phycis phycis } \\
\text { (Linnaeus, 1766) }\end{array}$ & $334(333-335)$ & $668(650-685)$ & -17.95 & 0.3 & 10.73 & 0.33 & 3 & 9 & 3 \\
\hline Scorpaenidae & $\begin{array}{l}\text { Scorpaena notata } \\
\text { Rafinesque, } 1810\end{array}$ & $112(68-148)$ & $65(10-195)$ & -17.66 & 0.39 & 10.15 & 0.5 & 33 & 41 & 27 \\
\hline
\end{tabular}




\begin{tabular}{|c|c|c|c|c|c|c|c|c|c|c|}
\hline & $\begin{array}{c}\text { Scorpaena porcus } \\
\text { Linnaeus, } 1758\end{array}$ & 142 (84-251) & $128(25-400)$ & -17.67 & 0.49 & 9.74 & 0.41 & 28 & 37 & 6 \\
\hline & $\begin{array}{c}\text { Scorpaena scrofa } \\
\text { Linnaeus, } 1758\end{array}$ & $177(124-217)$ & $275(80-535)$ & -18.07 & 0.22 & 10.06 & 0.23 & 5 & 18 & 3 \\
\hline Serranidae & $\begin{array}{l}\text { Serranus cabrilla } \\
\text { (Linnaeus, 1758) }\end{array}$ & $139(114-169$ & $61(25-105)$ & -18.36 & 0.22 & 9.79 & 0.23 & 20 & 43 & 14 \\
\hline Soleidae & $\begin{array}{c}\text { Microchirus } \\
\text { variegatus } \\
\text { (Donovan, 1808) }\end{array}$ & $87(72-100)$ & $19(10-30)$ & -18.14 & 0.34 & 10.2 & 0.14 & 7 & 21 & 6 \\
\hline \multirow[t]{6}{*}{ Sparidae } & $\begin{array}{c}\text { Boops boops } \\
\text { (Linnaeus, 1758) }\end{array}$ & $158(101-222)$ & $69(30-195)$ & -19.90 & 0.29 & 8.46 & 0.32 & 33 & 33 & 30 \\
\hline & $\begin{array}{l}\text { Diplodus annularis } \\
\text { (Linnaeus, 1758) }\end{array}$ & $123(94-188)$ & $66(25-185)$ & -18.85 & 1.1 & 11.72 & 1.65 & 48 & 34 & 28 \\
\hline & $\begin{array}{l}\text { Diplodus sargus } \\
\text { (Linnaeus, 1758) }\end{array}$ & $158(142-195)$ & $158(100-285)$ & -18.77 & 0.69 & 11.54 & 0.73 & 5 & 13 & 4 \\
\hline & $\begin{array}{c}\text { Diplodus vulgaris } \\
\text { (Geoffroy Saint- } \\
\text { Hilaire, 1817) }\end{array}$ & $115(65-173)$ & $76(10-195)$ & -18.14 & 0.78 & 11.59 & 0.83 & 20 & 58 & 12 \\
\hline & $\begin{array}{l}\text { Pagellus acarne } \\
\text { (Risso, 1827) }\end{array}$ & $118(97-190)$ & $47(20-145)$ & -17.76 & 0.6 & 10.64 & 0.56 & 20 & 36 & 11 \\
\hline & $\begin{array}{c}\text { Pagellus } \\
\text { erythrinus } \\
\text { (Linnaeus, 1758) }\end{array}$ & $147(115-162)$ & $72(40-105)$ & -17.77 & 0.26 & 10.81 & 0.6 & 5 & 32 & 3 \\
\hline Sphyraenidae & $\begin{array}{c}\text { Sphyraena } \\
\text { viridensis } \\
\text { Cuvier, } 1829\end{array}$ & $394(373-414)$ & $355(295-395)$ & -19.33 & 0.85 & 11.07 & 0.65 & 5 & 10 & 3 \\
\hline Synodontidae & $\begin{array}{l}\text { Synodus saurus } \\
\text { (Linnaeus, 1758) }\end{array}$ & $207(161-235)$ & $115(40-170)$ & -18.30 & 0.46 & 10.5 & 0.79 & 3 & 9 & 2 \\
\hline Triglidae & $\begin{array}{c}\text { Trigloporus } \\
\text { lastoviza } \\
\text { (Bonnaterre, 1788) }\end{array}$ & $148(102-195)$ & $76(20-155)$ & -17.9 & 0.56 & 9.76 & 1.07 & 3 & 9 & 2 \\
\hline
\end{tabular}


Table 2: Weight percentage for prey taxa in stomach content, prey representing less than $1 \%$ are presented with + symbol. Trophic group were determined by hierarchical clustering on stomach contents. Zoo: zooplankton feeders, MesoRB: rocky/ seagrass bottom mesocarnivores, MesoSB: muddy/ sandy bottom mesocarnivores, Macroc: macrocarnivores, Pisc: piscivores. SI group: groups resulting from the clustering analysis on SI ratios. Prim prod: primary producers, Cepha: cephalopods, Gastr: gastropods, Bival: bivalves, Polyc: polychaetes, Zoopk: zooplanktonic crustaceans, Crust: benthic crustaceans, Echin: echinoderms, Ascid: ascidians. Groups with minor contribution were pooled in "Others" and represented by superscript letters (b: bryozoans, c: cnidarians, h: hydrozoans, f: foraminifera, u: unidentified matter).

\begin{tabular}{|c|c|c|c|c|c|c|c|c|c|c|c|c|c|}
\hline Species & $\begin{array}{l}\text { Trophic } \\
\text { group }\end{array}$ & SI group & Prim prod & Cepha & Gastr & Bival & Polyc & Zoopk & Crust & Echin & Ascid & Fish & Others \\
\hline Boops boops & Zoo & 1 & 4 & - & 10 & 1 & - & 69 & - & - & - & 14 & $2^{c+u}$ \\
\hline Spicara smaris & Zoo & 1 & 2 & - & 20 & - & - & 78 & - & - & - & - & - \\
\hline Spicara maena & Zoo & 1 & - & - & - & - & 9 & 91 & - & - & - & - & - \\
\hline Coris julis & MesoRB & 2 & - & - & + & 86 & 3 & - & 11 & - & - & - & - \\
\hline Symphodus tinca & MesoRB & 2 & - & - & 10 & 21 & 41 & - & 8 & - & - & - & $29^{b+f+u}$ \\
\hline S. mediterraneus & MesoRB & 2 & 3 & - & 6 & 47 & + & - & 6 & & & & $37^{\mathrm{u}}$ \\
\hline Diplodus annularis & MesoRB & 3 & 87 & - & + & + & + & - & + & - & 2 & 6 & $2^{b+h+f+u}$ \\
\hline Diplodus sargus & MesoRB & 3 & 6 & - & + & 1 & 86 & - & - & - & 7 & - & - \\
\hline Diplodus vulgaris & MesoRB & 3 & - & - & 6 & - & 10 & - & - & 8 & 47 & - & $29^{b+h}$ \\
\hline Microchirus variegatus & MesoSB & 4 & - & - & 11 & - & 21 & - & 19 & 49 & - & - & - \\
\hline Mullus surmuletus & MesosB & 4 & 2 & - & + & 13 & 13 & - & 47 & 24 & - & - & $+^{\mathrm{u}}$ \\
\hline Pagellus acarne & MesoSB & 4 & 3 & - & 6 & 6 & 7 & - & 20 & 56 & 2 & - & - \\
\hline Pagellus erythrinus & MesoSB & 4 & - & - & 32 & - & - & - & 45 & 24 & - & - & - \\
\hline Trigloporus lastoviza & MesoSB & 4 & - & 62 & - & - & - & - & 38 & - & - & - & - \\
\hline Scorpaena notata & Macroc & 4 & - & - & - & 3 & - & - & 97 & - & - & - & - \\
\hline Scorpaena porcus & Macroc & 4 & + & - & - & - & + & - & 99 & - & - & - & - \\
\hline
\end{tabular}


Table 2 (continued)

\begin{tabular}{|c|c|c|c|c|c|c|c|c|c|c|c|c|c|}
\hline Serranus cabrilla & Macroc & 4 & - & - & - & - & + & - & 91 & - & - & 9 & - \\
\hline Synodus saurus & Pisc & 4 & - & - & - & - & - & - & - & - & - & 100 & - \\
\hline Scorpaena scrofa & Pisc & 4 & - & - & - & - & - & - & 15 & - & - & 85 & - \\
\hline Phycis phycis & Pisc & 4 & - & - & - & - & - & - & 4 & - & - & 96 & - \\
\hline Sphyraena viridensis & Pisc & 5 & - & - & - & - & - & - & + & - & - & 100 & - \\
\hline Dicentrarchus labrax & Pisc & 6 & - & - & - & - & - & - & - & - & - & 100 & - \\
\hline Trachurus mediterraneus & Pisc & 6 & - & - & - & - & - & - & 1 & - & - & 99 & - \\
\hline
\end{tabular}


Table 3: Comparison of trophic levels of artificial reef fishes. Trophic levels (TL) were issued from bibliographical data when based on stomach contents, with superscript letters standing for the reference used, or were calculated from the stable isotopic values recorded in this study, using the formula of Badalamenti et al. (2002): $N T_{i}=1+\left(\delta^{15} N_{i}-\delta^{15} N_{B}\right) / 3.4$, with $\delta^{15} N_{i}$ the $\delta{ }^{15} \mathrm{~N}$ value of fish species $\mathrm{i}, 3.4$ the theoretical trophic enrichment factor, and $\delta{ }^{15} \mathrm{~N}_{B}$ the isotopic ratio of the trophic baseline. Nanophytoplankton $\left(\delta^{15} \mathrm{~N}=1.77 \%\right.$ ) or macroalgae $\left(\delta^{15} \mathrm{~N}=3.91 \%\right.$ ) were used as proxies of pelagic or benthic trophic baselines.

\begin{tabular}{|c|c|c|c|c|}
\hline \multirow{2}{*}{ Trophic groups } & \multirow{2}{*}{ Species } & \multirow{2}{*}{$\begin{array}{l}\text { Stomach } \\
\text { content TL }\end{array}$} & \multicolumn{2}{|c|}{ Stable isotope TL } \\
\hline & & & Pelagic & Benthic \\
\hline \multirow{4}{*}{$\begin{array}{r}\text { Zooplankton } \\
\text { feeders }\end{array}$} & Boops boops & $2.5^{\mathrm{a}}$ & 3.0 & 2.3 \\
\hline & Spicara smaris & $3.0^{a}$ & 3.0 & 2.4 \\
\hline & Spicara maena & $3.2^{\mathrm{a}}$ & 2.8 & 2.2 \\
\hline & Mean & $2.8 \pm 0.3$ & $2.9 \pm 0.2$ & $2.3 \pm 0.2$ \\
\hline \multirow[t]{4}{*}{ Labrids } & Coris julis & $3.3^{a}$ & 3.3 & 2.7 \\
\hline & S. tinca & $3.3^{a}$ & 3.3 & 2.7 \\
\hline & S. mediterraneus & $3.2^{a}$ & 3.2 & 2.5 \\
\hline & Mean & $3.3 \pm 0.1$ & $3.3 \pm 0.1$ & $2.6 \pm 0.1$ \\
\hline \multirow[t]{4}{*}{ Diplodus spp. } & Diplodus annularis & $3.4^{\mathrm{a}}$ & 3.9 & 3.3 \\
\hline & Diplodus sargus & $3.4^{\mathrm{a}}$ & 3.9 & 3.2 \\
\hline & Diplodus vulgaris & $3.1^{\mathrm{a}}$ & 3.9 & 3.3 \\
\hline & Mean & $3.3 \pm 0.2$ & $3.9 \pm 0.4$ & $3.3 \pm 0.4$ \\
\hline \multirow{6}{*}{$\begin{array}{r}\text { Muddy or sand } \\
\text { bottom } \\
\text { mesocarnivores }\end{array}$} & M. variegatus & $3.4^{b}$ & 3.5 & 2.8 \\
\hline & Mullus surmuletus & $3.3^{a}$ & 3.4 & 2.8 \\
\hline & Pagellus acarne & $3.7^{\mathrm{a}}$ & 3.6 & 3.0 \\
\hline & Pagellus erythrinus & $3.3^{\mathrm{a}}$ & 3.7 & 3.0 \\
\hline & Trigloporus lastoviza & $3.5^{\mathrm{a}}$ & 3.3 & 2.7 \\
\hline & Mean & $3.4 \pm 0.2$ & $3.5 \pm 0.2$ & $2.9 \pm 0.2$ \\
\hline \multirow[t]{4}{*}{ Macrocarnivores } & Scorpaena notata & $3.5^{a}$ & 3.5 & 2.8 \\
\hline & Scorpaena porcus & $4.0^{\mathrm{a}}$ & 3.3 & 2.7 \\
\hline & Serranus cabrilla & $3.4^{\mathrm{a}}$ & 3.4 & 2.7 \\
\hline & Mean & $3.6 \pm 0.3$ & $3.5 \pm 0.1$ & $2.8 \pm 0.1$ \\
\hline \multirow{4}{*}{$\begin{array}{r}\text { Benthic } \\
\text { piscivores }\end{array}$} & Scorpaena scrofa & $4.1^{\mathrm{a}}$ & 3.4 & 2.8 \\
\hline & Synodus saurus & $4.5^{c}$ & 3.6 & 2.9 \\
\hline & Phycis phycis & $4.1^{\mathrm{a}}$ & 3.6 & 3.0 \\
\hline & Mean & $4.2 \pm 0.2$ & $3.5 \pm 0.2$ & $2.9 \pm 0.2$ \\
\hline \multirow{4}{*}{$\begin{array}{r}\text { Pelagic } \\
\text { piscivores }\end{array}$} & Dicentrarchus labrax & $4.3^{d}$ & 4.6 & 3.9 \\
\hline & T. mediterraneus & $3.5^{\mathrm{a}}$ & 4.9 & 4.2 \\
\hline & S. viridensis & $4.3^{\mathrm{e}}$ & 3.7 & 3.1 \\
\hline & Mean & $4.0 \pm 0.5$ & $4.4 \pm 0.7$ & $3.8 \pm 0.7$ \\
\hline
\end{tabular}

a: Stergiou and Karpouzi (2002) ; b: Darnaude (2005) ; c: Soares et al. (2003) ; d: Rogdakis et al. (2010) ; e: Barreiros et al. (2002) 


\section{Supporting information}

Supporting information may be found in the online version of the paper

Table S.1: Actual sampling at each season and each reef

\begin{tabular}{|c|c|c|c|c|c|}
\hline \multirow{2}{*}{ Family } & \multirow{2}{*}{ Species } & \multicolumn{2}{|c|}{ Winter } & \multicolumn{2}{|c|}{ Summer } \\
\hline & & V3 & V6 & V3 & V6 \\
\hline Carangidae & Trachurus mediterraneus & & 5 & & \\
\hline \multirow[t]{2}{*}{ Centracantidae } & Spicara maena & 1 & 2 & 3 & 4 \\
\hline & Spicara smaris & 7 & 1 & & 1 \\
\hline \multirow[t]{3}{*}{ Labridae } & Coris julis & 8 & 5 & & \\
\hline & Symphodus mediterraneus & & 2 & 1 & 2 \\
\hline & Symphodus tinca & & 1 & 2 & 3 \\
\hline Moronidae & Dicentrarchus labrax & 1 & 3 & & \\
\hline Mullidae & Mullus surmuletus & 4 & 12 & 13 & 6 \\
\hline Phycidae & Phycis phycis & 1 & 2 & & \\
\hline \multirow[t]{3}{*}{ Scorpaenidae } & Scorpaena notata & 12 & 6 & 8 & 7 \\
\hline & Scorpaena porcus & 5 & 4 & 10 & 9 \\
\hline & Scorpaena scrofa & 2 & & 2 & 1 \\
\hline Serranidae & Serranus cabrilla & 6 & 5 & 3 & 6 \\
\hline Soleidae & Microchirus variegatus & & 1 & 6 & \\
\hline \multirow[t]{6}{*}{ Sparidae } & Boops boops & 17 & 3 & 9 & 4 \\
\hline & Diplodus annularis & 7 & 33 & 3 & 5 \\
\hline & Diplodus sargus & & 2 & 2 & 1 \\
\hline & Diplodus vulgaris & 4 & 5 & 5 & 6 \\
\hline & Pagellus acarne & 11 & 6 & 2 & 1 \\
\hline & Pagellus erythrinus & & & 3 & 2 \\
\hline Sphyraenidae & Sphyraena viridensis & & 5 & & \\
\hline Synodontidae & Synodus saurus & & 2 & 1 & \\
\hline Triglidae & Trigloporus lastoviza & & 1 & 2 & \\
\hline
\end{tabular}


Table S.2: Significant spatial or seasonal variations of mean isotopic ratios $\left(\delta^{13} C\right.$ and $\left.\delta^{15} N\right)$ of fishes on Marseilles" artificial reef $(n \geq 9)$. S: summer, W: winter. P test significance ${ }^{* * *}$ for $p-$ value $\leq 0.001,{ }^{* *}$ for $p$-value $\leq 0.01,{ }^{*}$ for $p$-value $\left.\leq 0.05\right)$. Post-Hoc: results of post-hoc comparison of means

\begin{tabular}{|c|c|c|c|c|c|c|c|}
\hline \multirow{2}{*}{$\mathrm{n}$ indiv } & \multirow{2}{*}{ Species } & Factor & Values (\%o) & test & Statistics & $\mathrm{P}$ & Post-Hoc \\
\hline & & \multicolumn{6}{|c|}{$\delta^{13} \mathrm{C}$} \\
\hline \multirow[t]{2}{*}{10} & Spicara maena & Season & $\begin{array}{c}\text { S: }-19.68 \pm 0.27 \\
W:-19.18 \pm 0.12\end{array}$ & ANCOVA & 7.69 & * & $S<W$ \\
\hline & & \multicolumn{6}{|c|}{$\delta^{15} \mathrm{~N}$} \\
\hline 28 & Scorpaena porcus & Season & $\begin{array}{l}\text { S: } 9.57 \pm 0.35 \\
W: 9.94 \pm 0.40\end{array}$ & ANOVA & 9.03 & ** & $\mathrm{S}<\mathrm{W}$ \\
\hline 9 & Spicara smaris & Season & $\begin{array}{c}\text { S: } 9.26 \pm 0.02 \\
W: 8.42 \pm 0.78\end{array}$ & ANOVA & 9.29 & * & $S>W$ \\
\hline 35 & Mullus surmuletus & Reef & $\begin{array}{c}\text { V3: } 9.83 \pm 0.84 \\
\text { V6: } 10.03 \pm 0.46\end{array}$ & ANCOVA & 4.29 & * & $\mathrm{V} 3<\mathrm{V} 6$ \\
\hline
\end{tabular}


Table S.3: Parameters of the linear regression between stable isotopes values and standard length of fishes. Significant relationships are written in bold. $n$ : number of individuals. Linear relationships were considered to be significant when $n \geq 10, r \geq 0.5$ and $p \leq 0.05$. Due to the low number (3) of individuals, no regression was performed for Phycis phycis, Synodus saurus and Trigloporus lastoviza.

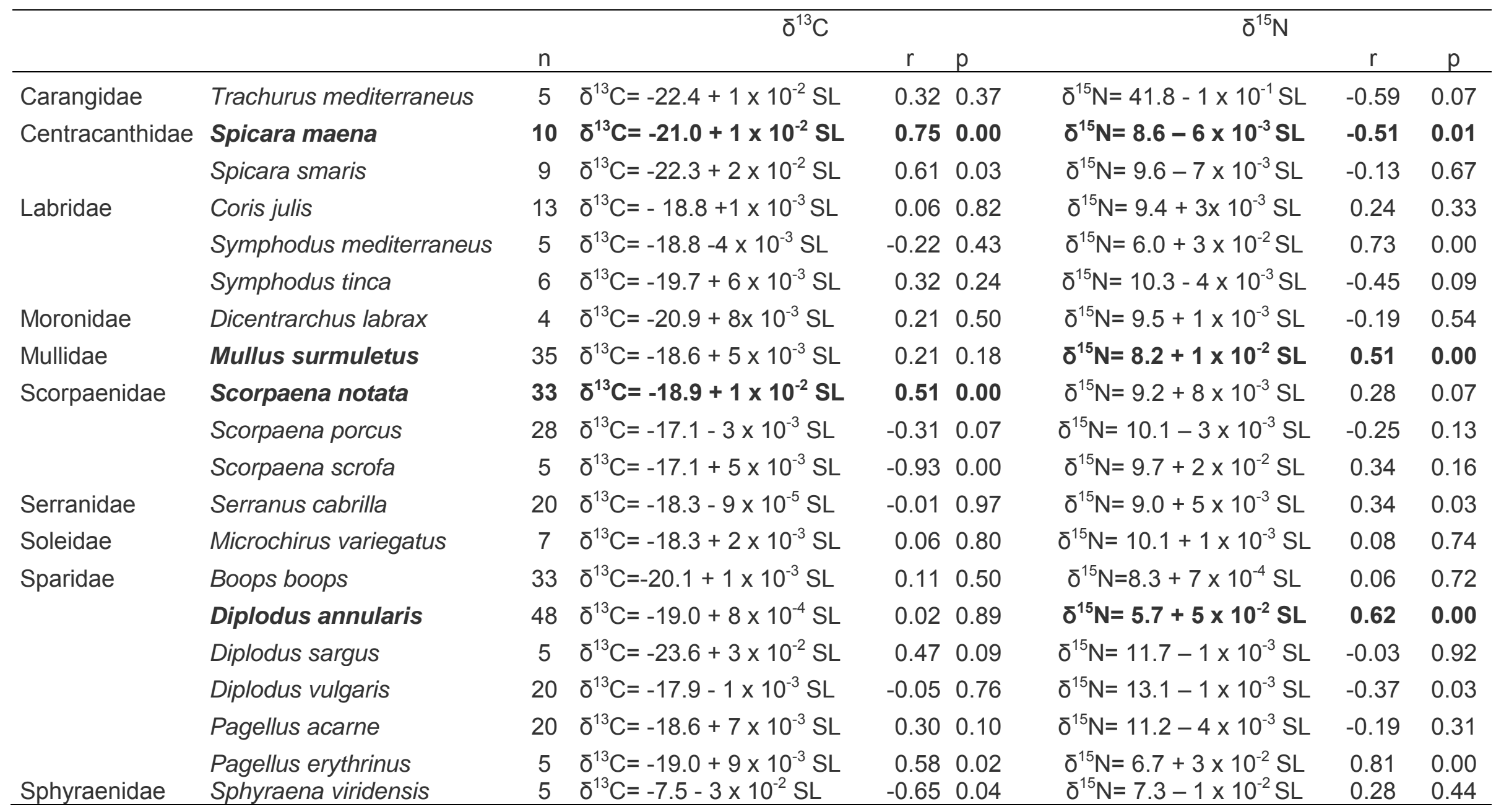

